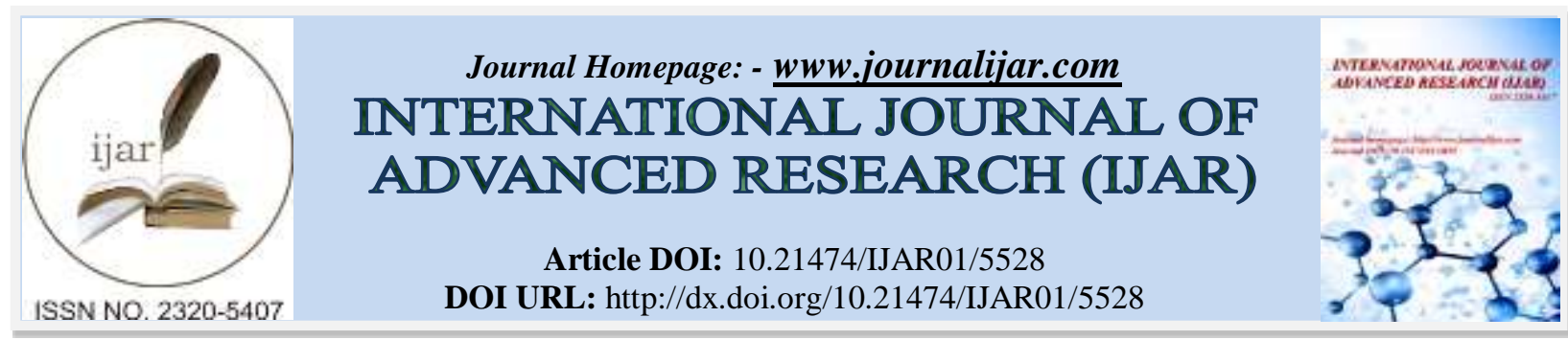

RESEARCH ARTICLE

\title{
EFFECT OF TEACHERS' ORGANIZATION OF CONTENT ON THE LEARNERS' ACQUISITION OF LINGUISTIC SKILLS AMONG SECONDARY SCHOOL STUDENTS IN BUNGOMA COUNTY, KENYA.
}

\author{
Matere Audrey $^{1}$, Peter O. Nyakan ${ }^{1}$ and Violet Nabwire Kafwa ${ }^{2}$. \\ 1. Department of Curriculum Instruction Studies and Media, Kisii University. \\ 2. School of Education, Moi University P.o Box 3900, Eldoret, Kenya.
}

\section{Manuscript Info}

Manuscript History

Received: 03 August 2017

Final Accepted: 05 September 2017

Published: October 2017

Key words:-

Teachers, Organization, Content, Learner, Linguistic skills.

\begin{abstract}
The aim of this study was to assess effect of teachers' organization of content on the learners' acquisition of linguistic skills among secondary school students in Bungoma County, Kenya. The study utilized descriptive survey research design using mixed methods approach. A sample size of 251 teachers, 371 students and 134 heads of languages department was used. Purposive, Proportionate and simple random sampling techniques was used to obtain the respondents. Data was collected using questionnaires, interview schedules, observation and document analysis. The validity of the instrument was tested through expert judgment while reliability was achieved using Cronbach Alpha. Quantitative data was analysed by use of frequencies and percentages while qualitative data was analysed thematically and presented in narrations and quotations. The study found that authentic teaching materials and planning of lessons by teachers was associated with learners' achievement of linguistic skills. Additionally, teachers had a negative attitude towards the adoption of integrated English approach. The study recommended that teachers need to adopt new strategies of assessing students. The findings of this study will be significant to teachers of English to re-evaluate their styles of teaching and improve on them. It may also assist curriculum planners and developers at Kenya Institute of Curriculum Development (KICD) on need to organize in-service course for teachers of English in line with the revised curriculum.
\end{abstract}

Copy Right, IJAR, 2017,. All rights reserved.

\section{Introduction:-}

For the past two centuries, the integration of English language studies with subject material content in recognized education has been given a significant attention in Europe, Asia, the Americas and Africa (Coyle, Hood, \& Marsh, 2010; Banegas, 2011; Lyster \& Ballinger, 2011; Navés, 2009; Moate, 2011). This integration according to DaltonPuffer \& Smit, (2007) has led to rebirth of two extensive teaching approaches; Content Based Instruction (CBI) and content and language integrated learning approach (CLIL).

The thinking of the integrated skills approach (ISA) originated from the idea that in normal, daily practice, oral and written languages were not separated and isolated from one another (Su, 2007). Peregoy \& Boyle (2001) on their part argue that oral and written languages are integrated in most communication occasions and often occur together. 
Integrated-skills approach, similarly, functions just as both communicative language teaching (CLT) and whole language do since they both stress on meaningful and dependable language usage and associate both written and oral language development (Su, 2007).

KIE, (2004) defines integration as amalgamation of two independent but related subjects, so as to augment each other. In English, writing, listening and speaking need to be complementary (MoE, 2012). Integration stresses the horizontal association between different curriculum parts with an aim of inter-relating content or learning experiences to enable the learners to observe a unity to knowledge (Roehrig et al., 2007). Roswell (2013) further describes the consequence of kinesthetic instruction as part of dependable, multidisciplinary form of interaction that creates an important element in inter-cultural literacy, which if amalgamated deliberately in the English classroom setting, could arouse, support and substantiate the spoken engagement of students.

In the syllabus review of 2002 in Kenya, a number of areas including poetry, plays, novels, summary writing, grammar and oral literature were found to be too difficult for pupils (K.I.E 2004). However, it was felt that these areas were primarily perceived as difficult due to the approach adopted in teaching them. The review therefore recommended that the oral aspect of poetry and oral literature be covered under the language skills of listening and speaking while the study of novels would be handled under intensive reading. On the other hand, summary writing skills would be taught under reading and writing. Grammar would be reorganized and content presented in a spiral approach under the broad areas of parts of speech, phrases, clauses and sentences (K.I.E 2004). This recommendation was adopted and led to a totally integrated English syllabus and strategy to the teaching and assessment of English in secondary school.

Further, Calderón, Slavin, and Sánchez (2011) asserted that quality of instruction matters a lot during English students' instructions. The researchers highlight comprehensive reorganization models, as well as individual parts of these models as school structures and leadership, integration of language, language and literacy instruction, literacy and content instruction in secondary schools, cooperative learning, professional advancement, parent and family support teams, coaching and monitoring implementation and results.

Scarcella (2003) noted that as learners' advance through secondary schools, academic content is deemed to become differentiated and multi-faced in relation to academic linguistic skills that is required by learners so as to meaningfully engage with and learn content. For ELL learners to successfully engage with scholastic content, they must have adequate academic language to attain new knowledge and skills and to show what they understand and can do in scholarly subjects. Thus, it is important that ELL learners be given with suitable supports to learn the language of the content areas and that these supports be aligned with the more rigorous content demands and higher achievement expectations associated with the CCSS. Only then can learners' construction of content knowledge improve hand in hand with the achievement of linguistic skills (Sato et al., 2011; Walqui \& van Lier, 2010).

Akram and Malik (2010) view successful integrative approach as inevitable support that would assist language teachers to make the lessons active, engage the students in different tasks and interactions during learning. Intense and efficient communicative learners are supposed to be involved the integration of the four linguistic skills, in which the teacher requires to create a positive environment, design appropriate tasks inspire students and deal with challenges according to learners' needs (Davis \& Pearse, 2000).

Educators argue that reading, speaking, listening and writing should be treated in the language learning process as combined, interdependent and intimate foundations of language and that no language development should be detached from the whole teaching chore. When a learner writes, reads, speaks, or listens, this language encounter feeds into a mutual information pond, and that in successive encounters with English language, this learner can draw on this pond $(\mathrm{Su}, 2007)$. Use of drama instructions has been pragmatic to the instruction of other languages which could either be first or second languages. In addition, Piazzoli (2011) adopted the use of drama workstations as part of a third-year Italian language teaching and found that the respondents in the research could yield more dependable and spontaneous language, in contrast to 'scripted' language where learners would normally find in a common English language class. From the results of the study, this was accredited to the engagement the respondents had to the role, settings that were appropriate to real life, and the theatrical tension that was formed in the drama lessons. 


\section{Statement of the Problem:-}

English is an essential subject in the core curriculum in Kenya. Being a compulsory subject and a means of instruction, there is need for teachers to perform well in the teaching of the subject matter. Although great importance has been placed on integration, very few guidelines are given to teachers on how to use integrated approach in achieving linguistic skills. The Kenya Certificate of Secondary Education (KCSE) English syllabus 2004 requires that the learner develops and achieves speaking, listening, reading and writing skills while using the language. Research has shown that $70 \%$ of classroom communication is teacher talk (Manyasi, 2014). This creates a great need to assess how Integrated English approach is used in achieving learners' linguistic development of skills. There are a few efforts in terms of in-service training given to teachers of integrated English (Gichuki, 2007). Previous -studies have shown that students' language skills benefitted from integrated English approach (Nold, Hartig, Hinz \& Rossa, 2008) but the effects of integrated English approach on achievement in the content subject remain unclear.

The problem of poor teaching of Integrated English has persisted (Otieno 2003). Anyanzwa and Otunga, (2007) and Barasa, (2005) postulated that the merging of English and Literature causes serious problems that lead to confusion, reduction in time allocation and resistance. In addition, lessening the number of lessons as a result of integration is double tragedy because the content is too much thus completion of syllabus is impossible.

Moseti (2007) noted that the effectiveness of integrated English curriculum depends on the quality of teachers that are there to translate the Integrated English syllabus to practical instructional material in class. Therefore, this study assessed the effect of teachers' organization of content on the learners' acquisition of linguistic skills among secondary school students in Bungoma County, Kenya

\section{Methodology:-}

The research used descriptive survey design using mixed approach methods. Mixed methodology is the blending of two or more approaches in a research study resulting in both quantitative and qualitative data (Greene, 2007; Teddlie \& Tashakkori, 2009; Creswell \& Plano Clark, 2007). The study was mixed methods in a single research which permits for pragmatism. The study targeted all the 724 teachers of English teaching Form three students in 206 secondary schools in Bungoma County. In addition, the study targeted all heads of languages department in all the 206 secondary schools. Form three teachers of English were specifically targeted for the purpose of this research because, it is at this level that set books are fully introduced according to the syllabus and thus the teacher is tasked with the responsibility of teaching the skills appropriately using integrated approach. The sample size formula for this study is Krejcie and Morgan (1970) as quoted by Kasomo (2001) where a sample size of 251 teachers and 134 heads of languages department was obtained.

The researcher stratified the respondents into the six administrative units; Bungoma Central sub-county, Bungoma East Sub-county, Bungoma West sub-county, Bungoma North sub-county, Bungoma south Sub-county and Mount Elgon Sub-county making Bungoma County. The researcher further employed stratified sampling technique to select the respondents from each of the administrative unit. Thereafter, simple random sampling was used to choose Form Three teachers of English involved in the study from each of the six administrative units. In addition, HODs in every selected school were selected purposively to take part in the study.

Questionnaires, interview schedules, observation and document analysis were the main data collection instruments used in this study. A pilot study was carried out in a neighbouring Kakamega County to establish the reliability of the research instrument. The content and structural validity of the instrument was tested by consulting supervisors of Kisii University and thereafter incorporating their positive inputs in the refining the final data collection instruments (Foxcroft, wood, Kew, Herrington \& Segal, 2004).

The quantitative data from the questionnaire was first subjected to preliminary processing through validation, coding and tabulation in readiness for analysis with the help of the statistical package for social science (SPSS) computer package. Frequencies, percentages, means and Standard deviation was used to analyze quantitative data. Data analysed was presented by use of tables and figures. Qualitative data from interview schedules, observation and document analysis was thematically classified and arranged before they were reported in narrations and quotations as per the research objectives. 


\section{Findings and Discussions:-}

The participants were asked to rate the effect of teachers' organization of content on the acquisition of linguistic skills. The outcome of the analyzed information is presented in Table 1.

Table 1:- Teachers' Responses on Effect of Organization of Content on Achievement of Linguistic Skills.

\begin{tabular}{|c|c|c|c|c|c|c|c|c|c|}
\hline \multirow[t]{2}{*}{ Statement } & \multicolumn{2}{|c|}{ SD } & \multicolumn{2}{|c|}{ D } & \multicolumn{2}{|c|}{$\mathbf{A}$} & \multicolumn{2}{|c|}{ SA } & \multirow{2}{*}{$\begin{array}{c}\text { Overall } \\
\text { Mean }\end{array}$} \\
\hline & $\mathrm{F}$ & $\%$ & $\mathrm{~F}$ & $\%$ & $\mathrm{~F}$ & $\%$ & $\mathrm{~F}$ & $\%$ & \\
\hline $\begin{array}{l}\text { Teaching of grammar through writing } \\
\text { itself improves the writing ability of } \\
\text { learners. }\end{array}$ & 23 & 9.7 & 27 & 11.4 & 61 & 25.7 & 126 & 53.2 & 78.9 \\
\hline $\begin{array}{l}\text { Materials to be taught in poetry are } \\
\text { usually arranged in order of difficulty. }\end{array}$ & 164 & 69.2 & 73 & 30.8 & 0 & 0.0 & 0 & 0.0 & 100.0 \\
\hline $\begin{array}{l}\text { Teaching grammar using Drama } \\
\text { increases motivation while reducing } \\
\text { anxiety amongst students. }\end{array}$ & 84 & 35.4 & 0 & 0.0 & 73 & 30.8 & 80 & 33.8 & 64.6 \\
\hline $\begin{array}{l}\text { Usually, poetry topics are grouped } \\
\text { together in a related manner making it } \\
\text { easier for students to learn speaking } \\
\text { and listening skills. }\end{array}$ & 164 & 69.2 & 73 & 30.8 & 0 & 0.0 & 0 & 0.0 & 100.0 \\
\hline $\begin{array}{l}\text { Oral literature Learning has provided } \\
\text { experiences where learners } \\
\text { demonstrate what they have learned in } \\
\text { class using writing and speaking. }\end{array}$ & 10 & 4.2 & 20 & 8.4 & 84 & 35.4 & 123 & 51.9 & 87.3 \\
\hline
\end{tabular}

Table 1 shows that 126(53.2\%) teachers were strongly in agreement with the statement that teaching of grammar through writing itself improves the writing ability of learners, 61(25.7\%) teachers of English agreed with the statement and 27(11.4\%) teachers disagreed with the statement while $23(9.7 \%)$ teachers strongly disagreed with the statement. From the responses, a mean of 3.04 and a standard deviation of 1.081 was obtained on the statement showing that majority $(78.7 \%)$ of teachers of English believed that teaching of grammar through writing itself improves the writing ability of learners. This implied that learners need to be encouraged to practice writing more thus improving the skills and therefore writing skills would be taught under reading and writing. This is consistent with the arguments of Tommaso (2005) who showed that behind teaching grammar in context, grammar need to be instructed through the writing itself and this is attributed to the fact that learners have difficulty in transferring what they have learned in drills to their own writing. Therefore, it emerged that numerous approaches of contextualizing grammatical ideas can be used to enhance the writing ability of students. Moreover, Strickland \& Shanahan, (2004) pointed out that language is the foundation for ongoing literacy support and involves learning about the structure, vocabulary and grammar.

Further, 164(69.2\%) teachers strongly disagreed with the statement that materials taught in poetry were usually arranged in order of difficulty while 73(30.8\%) teachers disagreed with the statement. From the responses, a mean of 1.14 and a low standard deviation of 0.673 was obtained on the statement showing that all the teachers of English in secondary schools in Bungoma County reported that they never arranged materials taught in poetry in order of difficulty. This implied that poetry materials were taught as per the emerging themes rather than their difficulty. Moreover, Elting and Firkins, (2006) noted that dramatizing poetry improves students' language proficiency and encourages them in the development of confidence in using English as a communicative instrument.

In addition, 84(35.4\%) teachers were in disagreement with the statement that teaching grammar using Drama increases motivation while reducing anxiety amongst students, 80(33.8\%) teachers strongly agreed with the statement while 73(30.8\%) teachers agreed with the statement. From the responses, a mean of 2.69 and a standard deviation of .988 was obtained showing that a majority of the teachers of English in secondary schools in Bungoma County teaching grammar using drama increased motivation while reducing anxiety amongst students. This implied that use of drama could have a positive influence on learners' performance in English grammar due to its motivation effect. The study findings were found to be consistent with those of other researchers such as Maley \& Duff, (2005), Stinson (2009), Baldwin, (2012) and Rieg \& Paquette, (2009) amongst others who showed drama 
made English instructions interesting and more motivating to students. Their findings showed that students were more engaged, attentive, interested, and participated actively in their classes. These attributes are considered by Krashen, (2003) as essential for a student if they are to acquire and retain skills and knowledge that is taught. This shows that use of drama in teaching English grammar could enhances students' acquisition of linguistic skills especially the speaking skills. From the responses, it was shown that teachers never grouped related poetry topics and this could have a negative effect on students' ability to learn speaking and listening skills together.

Further, 164(69.2\%) teachers strongly disagreed with the statement that usually, poetry topics were grouped together in a related manner making it easier for students to learn speaking and listening skills while $73(30.8 \%)$ teachers disagreed with the statement. From the responses, a mean of 1.15 and a low standard deviation of .595 showing that all the teachers reported that they never grouped poetry topics together in related manner. From the responses, it can be shown that teachers never grouped related poetry topics and this could have a negative effect on students' ability to learn speaking and listening skills together. Manyasi, (2014) noted that teachers of English language can use short stories, poetry, plays and novels to supplement the grammar instruction.

Similarly, $123(51.9 \%)$ teachers strongly agreed with the statement that oral literature learning had provided experiences where learners demonstrated what they had learned in class using writing and speaking, 84(35.4\%) teachers agreed with the statement, 20(8.4\%) teachers disagreed with the statement while 10(4.25) teachers strongly disagreed with the statement. The responses showed a mean 2.76 and a standard deviation of 1.247 on the statement showing that a majority (87.3\%) of the teachers of English in secondary schools in Bungoma County believed that learning of oral literature had enabled learners to demonstrate what they had learned in class using writing and speaking. This implies that oral literature enhanced the acquisition of writing and speaking skills among the secondary school students. Peregoy and Boyle (2001) argue that oral and written languages are integrated in most communication events and often occur together. From the aforementioned, it can be argued that students who are good in oral literature and usually good writers and speakers. Furthermore, Brenes (2005) advises that the use oral literature enhances students to understand how the spoken method functions in actual contexts.

On interviewing Heads of Department of Languages on how teachers' organization of content enhanced achievement of linguistic Skills few of them noted that most of the teachers over relied on the text books and therefore they could not even group poetry topics together in a related manner to make it easier for students to learn speaking and listening skill. They had a lot of lessons and they lacked enough time to enable them to organize the content to enable them achieve linguistic skills. This is consistent with the work of Okwara (2009) who found in his study that teachers of English perceived teaching of integrated English as time consuming. This is further supported by Mbithe (2014) who noted that integrated English syllabus was too wide to cover within the little time allocated to English on the timetable and therefore schools needed to set aside enough time and resources for effective teaching of integrated English.

The researcher observed that in many of the lesson taught, the teachers had not organized the content in an organized manner to enhance the achievement of linguistic skills. Lesson development phase was teacher centered giving no room for the learners to actively participate in the lesson which enabled them to achieve linguistic skills. According to Hayatu et al (2017) use of different methods of teaching depend on the topics to be learned, the learners' ability, the time allocation, the objective of the lesson. Meanwhile, most of the current emphasis is on the use of learner-centered methods to teaching and learning. This is because learning itself is dynamic, the environment keeps changing and teaching strategies should also change to reflect the changes in the environment (Joseph, 2009). In this study therefore, the adoption and use of learner-centered teaching approaches need to be encouraged so as to enable learners to achieve the linguistic skills in English.

\section{Conclusion and Recommendation:-}

Adequate teacher preparation enabled learners to acquire linguistic skills integrated English. The preparation involves incorporating content material into language classes, storytelling during teaching of content in English and use of audio player equipment to teach English grammar. 


\section{References:-}

1. Akram, A. \& Malik, A. (2010). Integration of language learning skills in second language acquisition. International Journal of Arts and Sciences, 3(14): 231-240.

2. Anyanzwa, A. \& Otunga, R. (2007). Evaluation of Secondary School Level in Kenya: A Study of Bungoma District. The Educator, Journal of the school Education. Eldoret: Moi University Press.

3. Baldwin, P. (2012). With Drama in Mind: Real Learning in Imagined Worlds ( ${ }^{\text {nd }}$ ed.). London: Continuum International Publishing Group.

4. Banegas, D. (2011). Content and language integrated learning in Argentina 2008-2011. Latin American Journal of Content and Language Integrated Learning, 4(2), 32-48.

5. Barasa, P. L. (2005). English Language Teaching in Kenya Secondary School: Policy Training and Practice. Eldoret: Moi University Press.

6. Brenes, N. A (2005). Analyzing an Oral Narrative Using Discourse Analysis Tools: Observing How Spoken Language Works. Retrieved March 16, 2015, from http://redalyc. uaemex. mx/pdf/ 447/4450/04.pdf.

7. Calderon, M., Slavin, R., \& Sanchez, M. (2011). Effective instruction for English learners. The Future of Children, 21(1), 103-127.

8. Coyle, D., Hood, P., \& Marsh, D. (2010). CLIL content and language integrated learning. Cambridge: Cambridge University Press.

9. Creswell, J. W., \& Plano Clark V. L. (2007). Designing and Conducting Mixed Methods Research. Thousand Oaks, CA: Sage Publications.

10. Davis, P. \& Pearse, E. (2000). Success in English Teaching. OUP Oxford.

11. Elting, S. and Firkins, A. (2006). Dramatizing poetry in the second language classroom. English Teaching: Practice and Critique, 5, 3, 127-136.

12. Foxcroft. M., Wood, W., Kew, K., Herrington, M. \& Segal, N. (2004). Global Entrepreneurship Monitor South African Report [Online]. Available: http:// www. gbs.nct.ac.za/gbswebb/userfiles/gemsouthafrica2000pdf

13. Gichuki, A.W. (2007). Challenges Facing Teachers Implementing Revised English Curriculum in Public Secondary Schools in Othaya Division, Nyeri District, Kenya. Unpublished Med Thesis; Nairobi: Kenyatta University.

14. Greene, J. C. (2007). Mixed Methods in Social Inquiry. San Francisco, CA: John Wiley \& Sons.

15. Hayatu, I G., Mohammed, A. A. \& Badau, K.M (2017). Effective Teaching and Learning Strategies in Science and Mathematics to Improve Students' Academic Performance in Nigeria. British Journal of Education, Society \& Behavioural Science 19(1): 1-7.

16. Joseph R.P. (2009). Learning strategies instruction model; 2009. Available:http: //www. kucrl. org/simon.

17. Kasomo, D. (2001). Research methods in humanities and education. Kenya. Nairobi. Egerton University Press.

18. Kenya Institute of Education (2004). Report on the Monitoring of the Implementing of the Revised Secondary Curriculum. KIE Research Report Series No. 75 Nairobi: KIE.

19. Krashen, S. D. (2003). Explorations in Language Acquisition and Use. Portsmouth: Heinemann.

20. Krejcie, R.V, \& Morgan, D.W. (1970). Determining sample size for research activities. Educational \& Psychological measurement, 30, 607-610.

21. Lyster, R., \& Ballinger, S. (2011). Content-based language teaching: Convergent concerns across divergent contexts. Language Teaching Research, 15(3), 279-288.

22. Maley, A., \& Duff, A. (2005). Drama techniques: a resource book of communication activities for language teachers (3rd ed.). Cambridge: CUP.

23. Manyasi, N. B. (2014). Integrated approach in teaching English language: the practice in Kenya. International Journal of Education and Research, 2 (4), 253-264.

24. Manyasi, N. B. (2014). Integrated approach in teaching English language: the practice in Kenya. International Journal of Education and Research, 2 (4), 253-264.

25. Mbithe, C. N (2014). Influence of the new integrated English curriculum on students' performance in English at the Kenya certificate of secondary education in Masinga Division, Kenya. Unpublished Thesis, University of Nairobi.

26. Moate, J. (2011). Reconceptualising the role of talk in CLIL. Journal of Applied Language Studies, 5(2), 17-35.

27. Moseti, P. (2007). Teaching/ Learning strategies in integrated English course and their effect on performance in Manga Division, Nyamira District. Unpublished M. ED Thesis. Kenyatta University.

28. Navés, T. (2009). Effective content and language integrated learning (CLIL) programmes. In Y. Ruiz de Zarobe \& R. M. Jiménez Catalán (Eds.), Content and language integrated learning. Evidence from research in Europe (pp. 22-40). Bristol: Multilingual Matters. 
29. Okwara, M. (2009). Towards model of integrated English curriculum for secondary schools in Kenya. Unpublished paper, Maseno university.

30. Otieno N.O. (2003). Relationship between Secondary School Teacher Attitudes towards Integrated English Approach and their Teaching Performance: A Study of Rachuonyo District, Kenya: Unpublished Med Thesis. Nairobi: Kenyatta University.

31. Peregoy, S.F., \& Boyle, O.F. (2001). "Reading, writing, and learning in ESL." New York: Addison Wesley Longman.

32. Piazzoli, E. (2011). Process drama: the use of affective space to reduce language anxiety in the additional language learning classroom. RiDE: The Journal of Applied Theatre and Performance, 16(4).

33. Rieg, S. A., \& Paquette, K. R. (2009). Using Drama and Movement to Enhance English Language Learners' Literacy Development. Journal of Instructional Psychology, 36(2), 148.

34. Roehrig, G. H., Kruse, R. A., \& Kern, A. L. (2007). Teacher and school characteristics and their influence on curriculum implementation. Journal of Research in Science Teaching, 44, 883-907.

35. Roswell, J. (2013). Working with Multimodality: Rethinking Literacy in a Digital Age. New York: Routledge.

36. Sato, E., Lagunoff, R., \& Yeagley, P. (2011). Academic language and the Common Core State Standards: Implications for state and district implementation and supporting the achievement of English language learners. Paper presented at the annual meeting of the American Educational Research Association, New Orleans, LA.

37. Scarcella, R. (2003). Academic English: A conceptual framework (Technical Report 2003-1). Irvine: The University of California Linguistic Minority Research Institute. Retrieved from http://www.lmri. ucsb.edu/ publications/ 03_ scarcella.pdf.

38. Stinson, M. (2009). Drama is like Reversing Everything: Intervention Research as Teacher Professional Development. Research in Drama Education 14(2), 225-243.

39. Strickland, D. S., \& Shanahan, T. (2004). Laying the groundwork for literacy. Educational Leadership, 61(6), 74-77.

40. Su, Y. C. (2007). Students' changing views and integrated skills approach in Taiwan's EFL college classes. Asia Pacific Education Review. Vol. 8, No. 1, 27-40.

41. Teddlie, C. \& Tashakkori, A. (2009). Foundations of Mixed Methods Research. Thousand Oaks, CA: Sage Publications.

42. Tommaso, K. (2005). Why is Grammar Important for College Transition Students? Retrieved from http://www.collegetransition.org/promising/rp3.html.

43. Walqui, A., \& Heritage, M. (2012). Instruction for diverse groups of English language learners. Paper presented at the Understanding Language Conference, Stanford, CA. 